https://dx.doi.org/10.4314/ijs.v23i2.13

Ife Journal of Science vol. 23, no. 2 (2021)

\title{
BIOSYNTHESIS AND CHARACTERIZATIONS OF EXTRACELLULAR ENZYMES OF MICROBIAL ISOLATES FROM DAIRY INDUSTRIAL EFFLUENT
}

\author{
Awe-Mathias, C. A. K..$^{1,3}$, Osho, M. B..$^{2^{*}}$ and Onajobi, I. B. ${ }^{3}$ \\ ${ }^{\prime}$ Department of Microbiology and Virology, College of Veterinary Medicine, Federal University of Agriculture, \\ Abeokuta, Nigeria. \\ ${ }^{2}$ Department of Biological Sciences (Microbiology Unit), College of Natural and Applied Sciences, McPherson \\ University, Seriki Sotayo, Ogun State, Nigeria. \\ ${ }^{3}$ Department of Microbiology, Faculty of Science, Olabisi Onabanjo University, Ago-Iwoye, Ogun State, Nigeria. \\ *Corresponding author's e-mail: oshomb@mcu.edu.ng; mikebamosho@gmail.com; Tel: +2348032698955; \\ $+2347059510010$
}

(Received: $13^{\text {th }}$ January, 2021; Accepted: $15^{\text {th }}$ July, 2021)

\section{ABSTRACT}

\begin{abstract}
Diary effluents are environmental pollutant which could serve as source of substrate for microbial enzymes' synthesis. This research investigated the isolation and screening of bacteria and fungi with potential extracellular proteolytic and amylolytic properties from dairy effluents, and their characteristics for maximum enzyme production. Effluent from a dairy industry located in Ibadan, Nigeria, was collected for isolation and screening of microbial species for enzymatic activities. The Biological Oxygen Demand (BOD), Total Soluble Solid (TTS), and $\mathrm{pH}$ of the effluent were determined using standard procedures. The potential isolates were characterized morphologically and by molecular techniques. Proteolytic and amylolytic activities of isolates were investigated on skimmed milk starch agar respectively and optimized with varying $\mathrm{pH}(6.0-9.0)$, temperature $\left(27-60^{\circ} \mathrm{C}\right)$ and incubation period $(12-72 \mathrm{~h})$. Data were analyzed by Duncan Multiple Range Test. Biological Oxygen Demand, Total Soluble Solid and $\mathrm{pH}$ of the effluent were $14.67 \mathrm{mg} / \mathrm{L}, 13.33 \%$ and 7.58 respectively. Eleven isolates were positive for either protease or amylase synthesis, but only two showed both proteolytic and amylolytic activities and were molecularly characterized as Bacillus stratosphericus CM2HG6 and Aspergillus welwitschiae. Optimization showed that enzyme production by B. stratosphericus CM2HG6 was highest at $35^{\circ} \mathrm{C}, \mathrm{pH} 7.0$ for $48 \mathrm{~h}$, and that of $A$. welwitschiae achieved optimum production at $37^{\circ} \mathrm{C}, \mathrm{pH} 8.0$ for $72 \mathrm{~h}$. Under optimized conditions, Bacillus stratosphericus CM2HG6 was the highest amylase and protease producer (24.4 and $30.74 \mathrm{U} / \mathrm{ml}$ respectively), while $A$. welwitschiae was the lowest producer $(12.58$ and $18.8 \mathrm{U} / \mathrm{ml}$ respectively). The study successfully showed that these industrially-important enzymes can be produced by microbial strains isolated from dairy effluent, and production can be further optimized.
\end{abstract}

\section{INTRODUCTION}

In many unregulated climes, industrial effluents are typically discharged into receiving water bodies or disposed on land that are often used by the communities around for domestic, farming, and fishing activities. Sometimes effluents gain access into wells or streams within the community and sewage may drain directly into major watersheds with minimal or no treatment. Proliferation of industries has not only improved productivity but also resulted in release of toxic substances into the environment, creating health hazards. This has seriously affected normal operations of ecosystems, flora and fauna (Porwal et al., 2015). When untreated, sewage can have serious impacts on the quality of an environment and on the health of people. Several researchers have considerably paid attention to the industrial wastes, which are usually discharged on land or into different water bodies and resulting into degradation of environment (Chhonkar et al., 2000).

The wastewater produced from the dairy industry is organic and has very high alkalinity. When this is directly discharged into the river or any other sources of water, there will be rapid depletion in the dissolved oxygen level and this may lead to the bacterial and fungal formation in the river (Srimathi et al., 2020). The enzymatic activity of a microorganism is in many cases influenced by the environment. Proteolytic enzymes also known as proteases, peptidases or proteinases are group of enzymes that help breakdown protein in the digestive system. They begin protein catabolism by hydrolysis of the peptide bonds that link amino acids together in a polypeptide chain. Proteases are widely distributed in nature and have microbes 
as their main sources. They are one of the main industrial enzymes used in detergents for their remotion capacity of protein based textile stains, with additional applications in leather, food, pharmaceuticals industry and bioremediation processes (Lechuga et al., 2016).

In biotechnology, amylases are of the most important enzymes used for hydrolysis of starch molecules, in the manufacturing of highmolecular-mass branched dextrins and as a glazing agent for the production of rice cakes and powdery foods (Raveendran et al., 2018). Studies on crude amylase characterization by Samanta et al. (2013) revealed that optimum activity was at $\mathrm{pH} 8$ and $37^{\circ} \mathrm{C}$. The crude enzyme was stable for $24 \mathrm{~h}$ at $\mathrm{pH}$ range of $6-8$ at $37^{\circ} \mathrm{C}$. The enzymes were quite stable at $40^{\circ} \mathrm{C}$, while at $50^{\circ} \mathrm{C}$ the enzyme activities were lost. A reduction in enzyme activity was observed at temperatures above $40{ }^{\circ} \mathrm{C}$. According to Raju and Divakar (2013), physical factors are important in any fermentation for optimization of biochemical production. The important physical factors that determine the bioprocess are $\mathrm{pH}$, temperature, aeration and agitation. It was noted that the effect of temperature on amylase activity by solid state fermentation (SSF) revealed $40^{\circ} \mathrm{C}$ as optimum $(120 \pm 1.9 \mathrm{U} / \mathrm{ml})$, and subsequently the enzyme production decreased.

During the period 2014-2019, the global demand for protease market has grown at a compound annual growth rate (CAGR) of $5.3 \%$ and their demand is expected to increase much further as they find usefulness also in bioremediation processes and leather processing. In view of this, the study was aimed at biosynthesis and characterization of protease and amylase from microorganisms isolated from the effluent of a dairy company to assuage the market demand.

\section{MATERIALS AND METHODS \\ Materials}

Skimmed milk agar (Himedia, India), Nutrient agar (Oxoid, UK), Potato dextrose agar (Himedia, India), Starch agar media (Himedia, India), Bacteriological peptone (Oxoid, UK). All growth media were prepared according to manufacturer's instruction.

\section{Sample Collection}

Dairy effluent was obtained from a dairy company in Ibadan North West Local Government, Oyo State, Nigeria. It is at Latitude 7.40208/ N $7^{\circ} 24^{\circ}$ 7.486 “ and Longitude 3.871745/ E $3^{\circ} 52^{`} 18.28$ “. Sample was collected aseptically into presterilized sample bottle and transported to the laboratory under cold storage for further analysis. Effluent for Biochemical Oxygen Demand analysis was collected into $250 \mathrm{ml}$ glass bottle with glass stoppers. Samples were further kept at $4{ }^{\circ} \mathrm{C}$ until required.

\section{Physicochemical Analysis of the Effluent \\ Determination of $\mathrm{pH}$}

The $\mathrm{pH}$ was determined in-situ using a $\mathrm{pH}$ meter (HANNA HI 9820, Hanna Instrument, Woonsocket USA) via the method described by APHA (2005). The electrode was washed initially with distilled water and thereafter standardized using phosphate buffer solution ( $\mathrm{pH}$ 7.2). The $\mathrm{pH}$ of the samples was measured afterwards and the readings recorded appropriately.

\section{Determination of Biological Oxygen Demand (BOD)}

The Biological Oxygen Demand (BOD) of dairy effluent was determined using standard method previously described by APHA (2005). Dechlorination of the sample was done by adding 0.25N sodium sulphate at $\mathrm{pH}$ 6.5-7.5. Dissolved Oxygen (DO) meter was used to measure the initial DO of the samples which were placed in a specialized $300 \mathrm{ml}$ BOD bottles, afterwards, the samples were placed in a dark incubator at $20{ }^{\circ} \mathrm{C}$ for 5 days at $( \pm 3 \mathrm{~h})$. After incubation, the DO meter was used to measure the dissolved oxygen again. The final DO reading was then subtracted from the initial DO reading to give the BOD concentration $(\mathrm{mg} / \mathrm{l})$ of the samples.

\section{Isolation of Microorganisms from the Effluents}

Dairy effluent $(10 \mathrm{ml})$ sample was serially diluted and $1 \mathrm{ml}$ appropriate dilution was inoculated on Nutrient Agar (NA) and Potato Dextrose Agar (PDA) for isolation of bacteria and fungi respectively using the pour plate method. NA plates were incubated at $37^{\circ} \mathrm{C}$ for $24-48 \mathrm{~h}$, while PDA plates were incubated for $72-96$ h at $30^{\circ} \mathrm{C}$. Distinct colonies were sub-cultured on separate 
plates to obtain pure strains which were stored on agar slants at $4{ }^{\circ} \mathrm{C}$ until required for further studies. Prior to subsequent use, isolates were inoculated on fresh growth medium.

\section{Molecular Identification of Bacterial and Fungal Isolates}

Genomic DNA of bacterial and fungal isolates was isolated using the ZR Fungal/Bacterial DNA mini-Prep ${ }^{\mathrm{TM}} \mathrm{Kit}$ and its protocol. Fresh bacterial (24 h) and fungal (48 - $72 \mathrm{~h}$ ) broth culture were used for DNA isolation. Bacterial and fungal broth culture $(1 \mathrm{ml})$ in Eppendorf tubes were washed twice with phosphate-buffered saline (PBS; $1 \mathrm{ml})$ and centrifuged $(5,000 \mathrm{~g})$ for $5 \mathrm{~min}$. The pellet was transferred into a ZR Bashing Bead $^{\mathrm{TM}}$ Lysis Tube and genomic Lysis Buffer (750 $\mu \mathrm{l})$ was added as the tube was fitted unto a bead beater at maximum speed of 10,000 rpm for 1 min. The mixture was centrifuged $(10,000 \mathrm{rpm})$ for one minute in a Zymo-Spin ${ }^{\mathrm{TM}}$ IV spin filter column; the filtrate was treated with fungal/bacterial DNA binding buffer $(1200 \mu \mathrm{l})$ supplemented with $0.5 \% \beta$-mercaptoethanol (6 $\mu \mathrm{l})$ and mixture centrifuged $(10,000 \mathrm{rpm})$ for 1 min. Genomic DNA in Zymo-Spin ${ }^{\mathrm{TM}}$ column was further purified by twice adding $200 \mu \mathrm{l}$ DNA prewash buffer and centrifuging $(10,000 \mathrm{rpm})$ for one minute. DNA Elution Buffer $(\geqslant 50 \mu \mathrm{l})$ was subsequently added to spin column and incubated for $2-5 \mathrm{~min}$ at room temperature and column centrifuged afterwards at $10,000 \mathrm{rpm}$ for $30 \mathrm{~s}$ to obtain pure DNA in supernatant. Successful DNA purification was confirmed via agarose gel electrophoresis.

Polymerase chain reaction (PCR) amplification of both 16S rRNA and 18S rDNA genes of the purified DNA extracts was carried out. Universal primers (27F 5'-AGAGTTTGATCCT GGC TCAG-3' a n d $1492 \mathrm{R}$ 5' GGTTACCTTGTTACGACT'T-3') were used for the detection of Bacillus stratosphericus CM2HG6 while specific primers nu-SSU-0817-5' (T'TAGCATGGAATAATRRAATAGGA) and nu - S S U - 1 196-3' (T C T G G A C C T GGTGAGTTTCC) were used for detection of $A$. welwitschiae. The PCR amplification was performed using a Mini Cycler PTC-150 (MJ Research, Inc., Watertown, MA) with a primary heating step for $2 \mathrm{~min}$ at $95{ }^{\circ} \mathrm{C}$, followed by 30 cycles of denaturation for $20 \mathrm{~s}$ at $95^{\circ} \mathrm{C}$, annealing for $60 \mathrm{~s}$ at $55^{\circ} \mathrm{C}$ and extension for $2 \mathrm{~min}$ at $72{ }^{\circ} \mathrm{C}$, then followed by a final extension step for $7 \mathrm{~min}$ at $72{ }^{\circ} \mathrm{C}$. Each $25 \mu \mathrm{l}$ reaction mixture contained $2 \mu \mathrm{l}$ of purified template genomic DNA. The PCR amplified products were analyzed on $1 \%$ agarose gel electrophoresis containing ethidium bromide $(0.5 \mathrm{mg} / \mathrm{ml})$ and $1 \mathrm{~kb}$ DNA molecular weight marker and documented using a gel documentation system (Thermo Fisher Scientific, India). The PCR amplicon for the partial 16srRNA gene were further processed by sequencing.

Sequencing was carried out using dideoxy chain reaction with the same set of primers in both directions to check for validity of the sequence. Nucleotide sequences obtained were analyzed using the Basic Local Alignment Search Tool (BLAST-N) at the National Center for Biotechnology Information (NCBI) gene database to identify the isolates in relation to sequenced nuclear materials of similar organisms present in the database.

\section{Phylogenetic Analyses of the Potential Isolates}

Phylogenetic and molecular evolutionary relatedness of the isolates as well as with Homologous sequences retrieved from the NCBI database were conducted in MEGA version 10.0 (Tamura et al., 2011). The 16S rRNA of the bacterial and $18 \mathrm{~S} \mathrm{rDNA}$ of the fungal gene sequences obtained for the identified isolates were assigned accession numbers which was used to determine the lineage of the isolates and their relationship with those that are present in the National Centre for Biotechnological Information (NCBI) database gene bank.

The nucleotide positions at which any of the sequences had gap or ambiguous bases were not included in the phylogenetic calculations. Boostrap values (per 1000 trials) are shown at the branch nodes. The taxonomic distances were determined using the most appropriate distance model ( $\mathrm{p}$-distance) and the phylogenetic tree was constructed using the Test Neighbour-Joining Tree for bacterial isolates and fungal isolates. 


\section{Screening for Proteolytic and Amylase Activities}

Assay for protease activity on growth medium was determined using method previously described by Sally (2000). Skimmed milk agar (Hardy Diagnostic, Santa Maria CA, USA) plates were spotted centrally on the surface with $0.1 \mathrm{ml} 24 \mathrm{~h}$ bacterial and fungal culture respectively. Plates were incubated at $30^{\circ} \mathrm{C}$ for $48 \mathrm{~h}$ and examined for clear zones around colony spots.

Screening for amylolytic activity of microbial species was determined according to the method of Padma and Pallavi (2016). Colony of pure bacterial culture was aseptically inoculated on starch agar medium (Avantor Inc, USA) with starch as the only carbon source by streaking. The plates were incubated at $37^{\circ} \mathrm{C}$ for $24-48 \mathrm{~h}$ for bacterial and at $30{ }^{\circ} \mathrm{C}$ for $72 \mathrm{~h}$ for fungal isolates. Afterwards, plates were flooded with Gram's iodine to produce a deep blue colored starchiodine complex. Absence of blue colouration around microbial colony describes a zone of degradation (hydrolysis) and this indicates positive amylolytic strain.

\section{Determination of Enzyme Activities}

Protease activity was determined by modified procedures of Sevinc et al., (2011). Four $15 \mathrm{ml}$ vials were used for different samples, and one was used as blank. To each of the four vials, $5 \mathrm{ml} 0.65 \%$ casein solution were added, and then equilibrated in a water bath at $37^{\circ} \mathrm{C}$ for $5 \mathrm{~min}$. Then $0.05,0.10$, 0.15 and $0.20 \mathrm{ml}$ volumes of the test sample solution were added to each vial including the blank, thereby making the final volume of enzyme solution in each vial to be $1 \mathrm{ml}$, which was then incubated at $37^{\circ} \mathrm{C}$ for $30 \mathrm{~min}$. The protease activity and consequential liberation of tyrosine during this incubation time was measured and compared against the test samples. Thereafter, 5 $\mathrm{ml}$ trichloroacetic acid (TCA) was added to each vial to stop the reaction. Tyrosine standard dilution was prepared by using six tubes containing $8 \mathrm{ml}$ volume. To the six tubes, $1.1 \mathrm{mM}$ tyrosine standard stock solutions were added with the following volumes in $\mathrm{ml}: 0,0.10,0.20,0.30$, 0.40 , and 0.50 .

Distilled water was added to make up to $2 \mathrm{ml}$. After 30 minutes incubation, the test samples were filtered plus the blank using a $0.45 \mu \mathrm{m}$ polyether sulfone syringe filter. Two (2) $\mathrm{ml}$ filtrate of the test sample and blank were added into 4 dram clear plastic vials that can hold $8 \mathrm{ml}$ by volume. Then 5 $\mathrm{ml}$ sodium carbonate was added to the dram vials to regulate the $\mathrm{pH}$ drop. Folin's reagent was added mixed by swirling and incubated at $37^{\circ} \mathrm{C}$ for 30 min. After incubation, the standards had varying gradation of colour correlating to the amount of tyrosine dissolved; the highest concentration of tyrosine appeared the darkest. Two (2) $\mathrm{ml}$ of filtrate were then dispensed into cuvettes using a $0.45 \mu \mathrm{m}$ polyether sulfone syringe filter. Absorbance was taken at $660 \mathrm{~nm}$, with the light path set to $1 \mathrm{~cm}$. The curve was generated by difference in absorbance between the standards and standard blank. This was the absorbance value attributed to the amount of tyrosine in the standard solution. Standard curve has absorbance of the standards on the Y-axis and the amount of tyrosine in micromoles for each of the five standards on the $\mathrm{X}$-axis.

Units $/ \mathrm{ml}$ enzyme $=(\mu \mathrm{mol}$ tyrosine equivalents released $) \times$ Total vol of assay

vol of enzyme $(\mathrm{ml}) \times$ Time of Assay $\times$ vol. used in colorimetric determination

Amylase activity was assayed as described by Bernfeld (1955) by pipetting $0.5 \mathrm{ml}$ culture extract enzyme into test tubes and $1 \mathrm{ml} 1 \%$ soluble starch in citrate phosphate buffer having $\mathrm{pH}$ 6.4. The reducing sugars liberated were estimated by the 3 , 5- Dinitrosalicyclic acid (DNS) method. The reaction mixture was incubated in a water bath at $40{ }^{\circ} \mathrm{C}$ for $30 \mathrm{~min}$. A blank consisting of $1 \mathrm{ml}$ soluble starch in citrate - phosphate buffer $(\mathrm{pH}$ 6.4) was also incubated in a water bath at the same temperature and time with the other test tubes. The reaction was terminated by adding $1 \mathrm{ml}$ DNS reagent in each test tube and then immersing the tubes in a boiling water bath for 5 min after which they were allowed to cool and $5 \mathrm{ml}$ distilled water was added. The absorbance for all the test tubes was measured at $540 \mathrm{~nm}$ with spectrophotometer.

Unit Definition: One unit will liberate $1.0 \mathrm{mg}$ of glucose from starch in $3 \mathrm{~min}$ at $\mathrm{pH} 6.9$ at $20^{\circ} \mathrm{C}$.

Units $/ \mathrm{mlenzyme}=(\mathrm{mg}$ of glucose released $)(\mathrm{df}) \mathrm{ml}$ of sample

Where $\mathrm{df}=$ dilution factor 


\section{Fermentation for Protease and Amylase Production}

Protease and amylase production was carried out in submerged fermentation according to the method of Padma and Pallavi (2016). Production medium contained $(\mathrm{g} / \mathrm{l})$ bacteriological peptone $6.0 \mathrm{~g}$, $\mathrm{MgSO}_{4} \cdot 7 \mathrm{H}_{2} \mathrm{O} 0.5 \mathrm{~g}, \mathrm{KCl} 0.5 \mathrm{~g}$, starch $10 \mathrm{~g}$ and $10 \mathrm{ml}$ skimmed milk in $100 \mathrm{ml}$ conical flasks. The flasks were sterilized in an autoclave at $121^{\circ} \mathrm{C}$ for $15 \mathrm{~min}$ and after cooling it was inoculated with overnight grown bacterial and fungal cultures respectively. Inoculated flasks were incubated at $37^{\circ} \mathrm{C}$ for $24 \mathrm{~h}$ and $27^{\circ} \mathrm{C}$ for $72 \mathrm{~h}$ for bacterial and fungal cultures respectively in a shaker incubator. At the end of fermentation period, culture medium was centrifuged at 5,000 rpm for $15 \mathrm{~min}$ to obtain the crude extract which served as enzyme source.

\section{Optimization of Culture Condition for} Protease and Amylase Production

Optimization of enzyme production was determined according to the method of Fossi et al. (2004). Factors considered during optimization of amylase and protease activities include $\mathrm{pH}$, temperature and incubation period.

\section{$\mathrm{pH}$}

The optimum $\mathrm{pH}$ for protease and amylase activities was determined by running the assay activity between $\mathrm{pH}$ ranges of $6.0,6.5,7.0,7.5,8.0$ and 9.0 respectively. The enzyme activity for each $\mathrm{pH}$ was determined using the method of Fossi et al., (2004). Adjustments of the $\mathrm{pH}$ were done by addition of hydrochloric acid $(0.1 \mathrm{M})$ or $0.1 \mathrm{M}$ sodium hydroxide to achieve desired acidity or alkalinity respectively. The flasks containing fungi culture were incubated at $37{ }^{\circ} \mathrm{C}$ for $48 \mathrm{~h}$. Samples were taken at regular intervals and analyzed for amylase and protease activities (Sharma et al., 2017).

\section{Temperature}

Temperature plays an important role in the production of enzyme. The effect of temperature on protease and amylase production was studied by incubating the culture media at various temperatures of $27,30,35,37,40,45,50$ and $60^{\circ} \mathrm{C}$ along with arbitrary control at $37^{\circ} \mathrm{C}$ and $40^{\circ} \mathrm{C}$. The enzyme assay was carried out after $24 \mathrm{~h}$ of incubation for the bacterial isolates and $72 \mathrm{~h}$ for the fungal isolates (Padma and Pallavi, 2016, Sharma et al., 2017).

\section{Incubation Period}

The protease and amylase production of the selected experimental microorganisms were determined by optimizing the production media. The experiment was carried out individually at various incubation periods such as 12, 24, 36, 48, 60 and $72 \mathrm{~h}$ (Sharma et al., 2017).

\section{Statistical Analysis}

The results obtained were analyzed with Statistical Package for Social Sciences (SPSS) version 18 by Duncan Multiple Range Test. Significant differences of triplicate mean values were determined at $\mathrm{p} \leqslant 0.05$.

\section{RESULTS}

\section{Physicochemical Parameters of the Effluents}

The physicochemical properties of the dairy effluent are shown in table 1. The Biological Oxygen Content (BOD) was measured as 14.67 $\mathrm{mg} / \mathrm{L}$, while the Total Soluble Solids (TSS) detected was $13.33 \%$. Furthermore, the $\mathrm{pH}$ of the solution was in the neutral range (7.58).

\section{Screening for Potential Enzyme Producers}

In the microbial screening procedure, eleven (11) isolates were obtained as pure cultures from the dairy effluents. Six (6) of these isolates were bacterial species, including Proteus sp., Bacillus sp., Staphylococcus aureus, Lactobacillus sp., Alcaligenes sp., and Enterococcus sp. Furthermore, five (5) fungal species were isolated from the dairy effluent and they include: Penicillium sp., Aspergillus sp., A. oryzae, Rhizopus sp. and Candida sp. Seven (7) isolates had amylolytic activity, while five (5) showed proteolytic activity potential. Proteus sp., S. aureus, Bacillus stratosphericus CM2HG6 and Lactobacillus sp. were bacterial isolates with amylolytic activity; while fungal species $A$. oryzae and $A$. welwitschiae also showed amylolytic activity. Similarly, bacterial isolates with proteolytic potential included Bacillus stratosphericus CM2HG6; while fungal isolates from dairy effluent with proteolytic activity potential included Trichoderma sp., A. welwitschiae and Candida sp.

The isolates that showed both amylolytic and proteolytic activities include one bacterial isolate: Bacillus stratosphericus CM2HG6 and fungal specie A. welwitschiae (Data not shown). These isolates were used for further studies. 
Table 1: Physicochemical Properties of Raw Dairy Effluent

\begin{tabular}{ll}
\hline Parameters & Raw Effluent \\
\hline BOD $(\mathrm{mg} / \mathrm{L})$ & $14.67 \pm 1.45$ \\
TSS $(\%)$ & $13.33 \pm 1.76$ \\
$\mathrm{pH}$ & $7.58 \pm 0.25$ \\
\hline
\end{tabular}

Values are means \pm standard deviation

Abbreviations: $\mathrm{BOD}=$ Biological Oxygen Demand; $\mathrm{TSS}=$ Total Soluble Solids

\section{Bacterial and Fungal Identifications}

Bacillus sp. is a motile rod-shaped organism, and has positive reaction to oxidase, catalase and citrate reagents. Similarly, the specie was negative for coagulase, urease and indole tests respectively. Furthermore, observation of the hyphae under the microscope showed that $A$. welwitschiae produces septate hyphae, while the spores are black in colour, produced on conidiophores.

Sequenced genes analyzed using the BLAST software were identified as Bacillus stratosphericus CM2HG6 (Accession Number: KU664829.1) and Aspergillus welwitschiae (Accession Number: MW332490.1).

Phylogenetic Characteristics of the Selected Isolates from Industrial Dairy Effluents

The phylogenetic relationship as illustrated in figure 1a, showed that Bacillus stratosphericus CM2HG6 isolated from industrial dairy effluent formed a cluster, depicting an associated evolutionary relationship with Bacillus sp. obtained from NCBI database gene bank. The $18 \mathrm{~S}$ rDNA gene sequence obtained for the identified fungal isolate was assigned accession number which was used to determine the lineage of the fungi isolated from industrial diary effluents in relation with isolates that are present in the National Centre for Biotechnological Information (NCBI) database gene bank. The nucleotide positions at which any of the sequences had gap or ambiguous bases were not included in the phylogenetic calculations. Bootstrap values (per 1000 trials) are shown at the branch nodes. The phylogenetic relationship of the fungal isolate as illustrated in figure $1 \mathrm{~b}$ showed that Aspergillus sp. isolated from industrial dairy effluent formed a cluster of associated evolutionary relationship with Aspergillus welwitschiae strain obtained from NCBI database gene bank.

Bacillus stratosphericus CM2HG6 (KU664829.1)

KF479648 Bacillus sp.

KF026331 Psychrobacillus psychrodurans

MN235886 Lysinbacillus sphaericus

MN177183 Lysinbacillus fusiformis

(a) 
Aspergillus welwitschiae (MW332490.1)

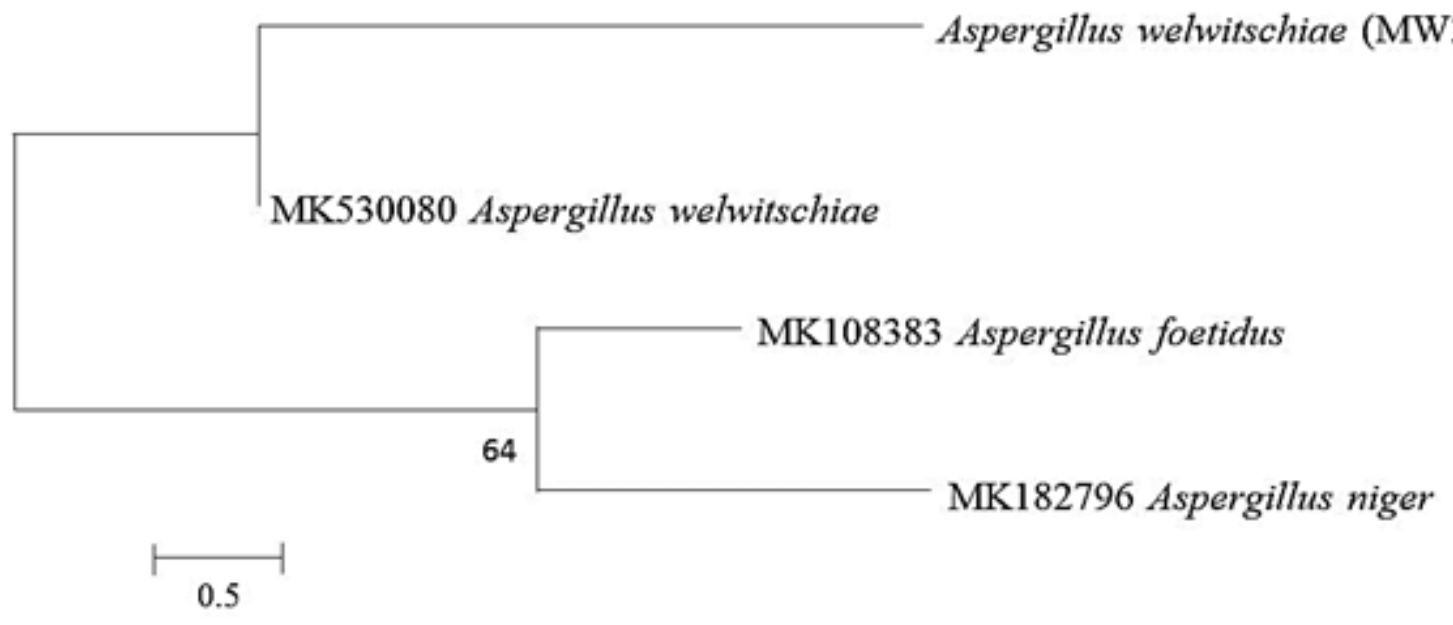

(b)

Figure 1: Molecular Phylogenetic Analyses of (a) Bacillus stratosphericus CM2HG6 (b) Aspergillus welwitschiae Isolated from Industrial Dairy Effluents by Maximum Likelihood method

Optimization Processes of Amylase and Protease Production

Optimization of protease and amylase enzyme production by all the two isolates based on temperature parameter is shown in figure 2 . Optimum amylase enzyme production $(8 \mathrm{U} / \mathrm{ml})$ for Bacillus stratosphericus CM2HG6 was at $30{ }^{\circ} \mathrm{C}$ while it was $15 \mathrm{U} / \mathrm{ml}$ at $40^{\circ} \mathrm{C}$ for $A$. welwitschiae respectively. Optimal proteolytic activities are also temperature-dependent as Bacillus stratosphericus CM2HG6 and A. welwitschiae had 9.4 and 13.8 $\mathrm{U} / \mathrm{ml}$ respectively. It was revealed that $A$. welwitschiae had the highest protease production potential while Bacillus stratosphericus CM2HG6 was the lowest.

A plot of enzyme activities against $\mathrm{pH}$ illustrating the effect of $\mathrm{pH}$ on protease and amylase production is shown in figure 3. Amylase production was optimum at $\mathrm{pH} 7.0$ for $B$. stratosphericus CM2HG6 $(8.0 \mathrm{U} / \mathrm{ml})$ whereas optimum enzyme production by $A$. welwitschiae was at $\mathrm{pH} 8.0(8.9 \mathrm{U} / \mathrm{ml})$. Optimum protease production was 9.9 and $13.7 \mathrm{U} / \mathrm{ml}$ respectively.

Effect of incubation period on protease and amylase production by Bacillus stratosphericus CM2HG6 and A. welwitschiae (Figure 4) showed that highest protease and amylase production was achieved at $24 \mathrm{~h}$ for Bacillus stratosphericus CM2HG6 (29.1 and $24 \mathrm{U} / \mathrm{ml}$ ) and $A$. welwitschiae (15.6 and $9.6 \mathrm{U} / \mathrm{ml}$ ) achieved optimum enzymes production at $72 \mathrm{~h}$.

Table 2 showed protease and amylase production by Bacillus stratosphericus CM2HG6 and $A$. welwitschiae under optimized conditions. $B$. stratosphericus CM2HG6 showed highest protease and amylase activities of 30.74 and $24.4 \mathrm{U} / \mathrm{ml}$ respectively, while $A$. welwitschiae produced lowest enzymes activities (18.8 and $12.58 \mathrm{U} / \mathrm{ml}$ for protease and amylase respectively). 

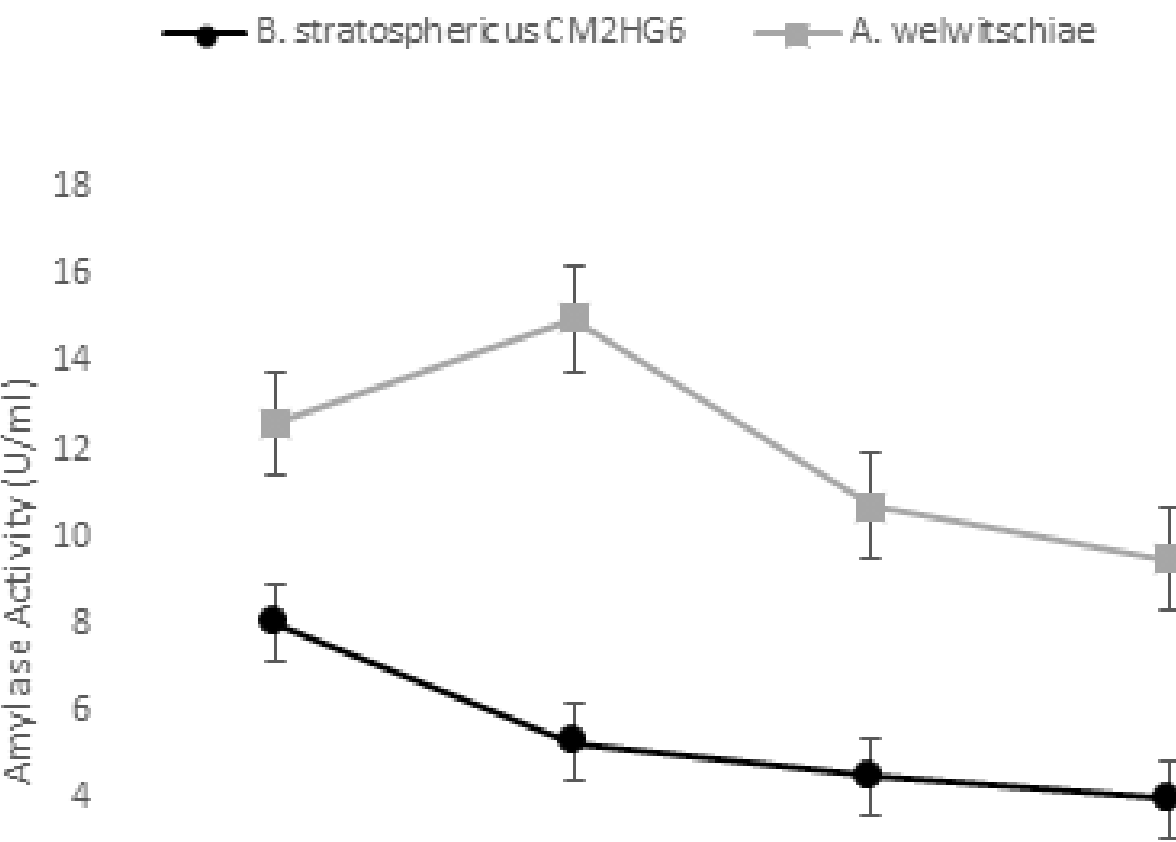

2

0

(a)

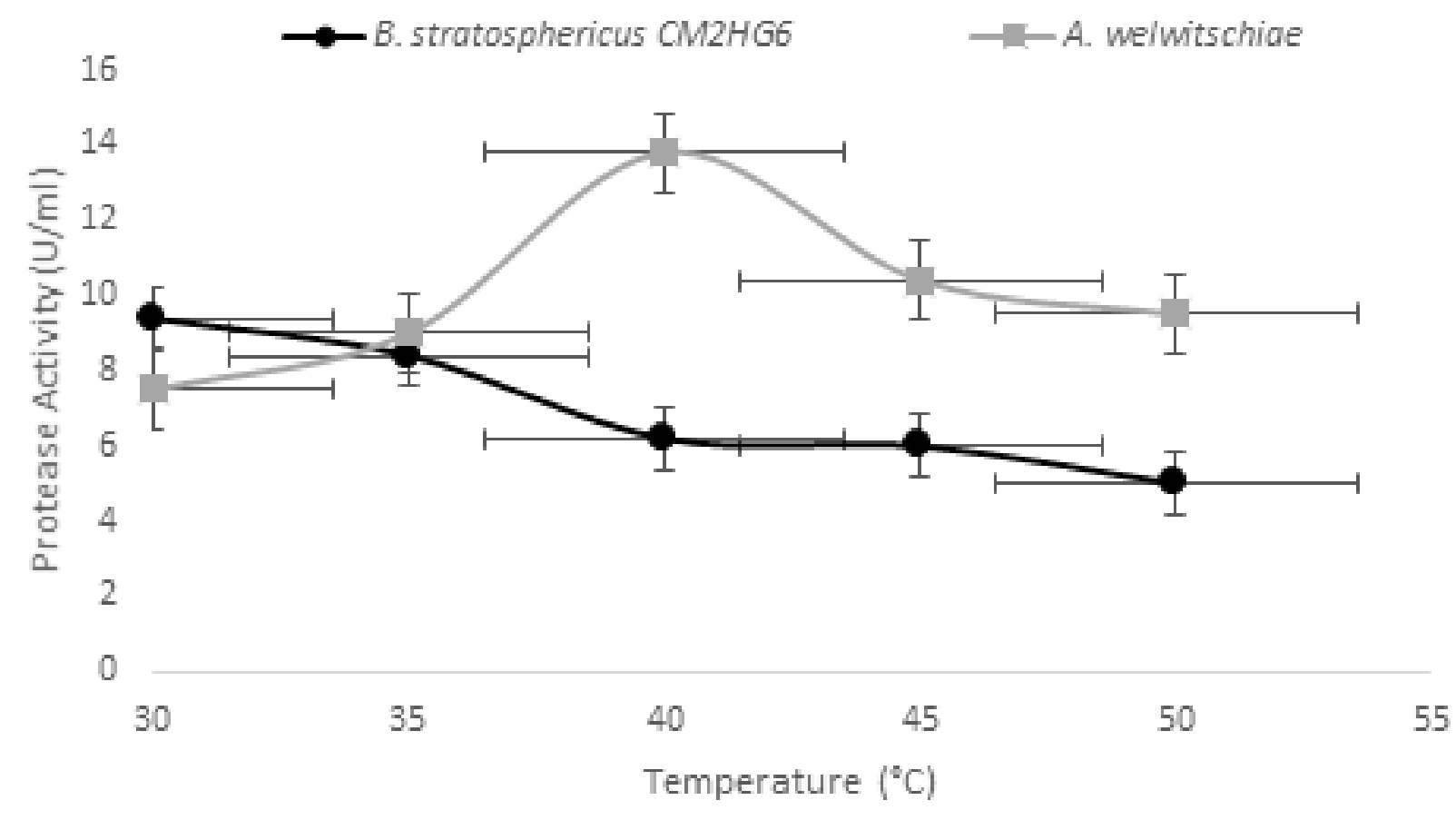

(b)

Figure 2: Optimization of (a) Amylase and (b) Protease Production by B. stratosphericus CM2HG6 and A. welwitschiae at Different Range of Temperature \pm 0.05 S.E. 


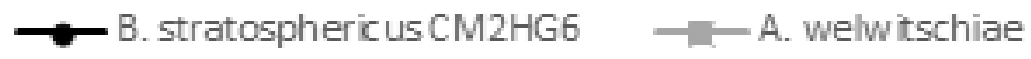

12

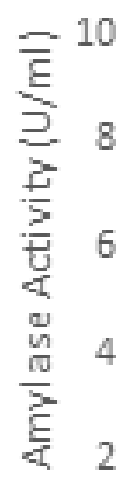

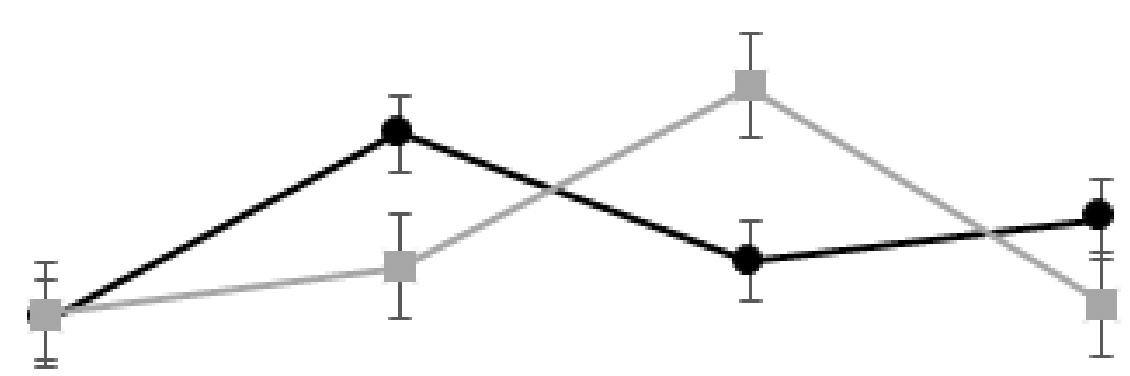

0

6

7

8

9

$\mathrm{pH}$

(a)

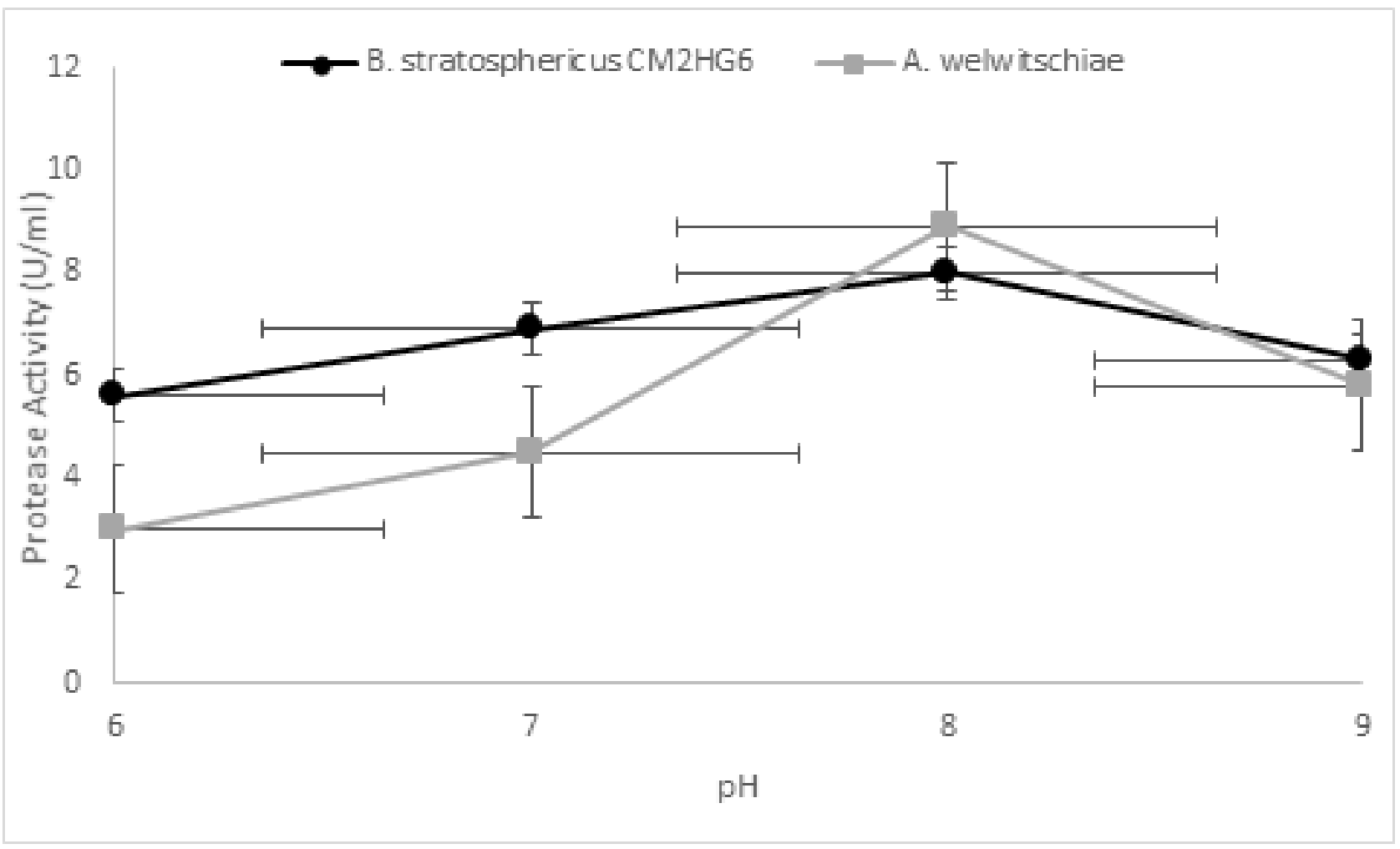

(b)

Figure 3: Optimization of (a) Amylase and (a) Protease production by B. stratosphericus CM2HG6 and $A$. welwitschiae based on Acidity and Alkalinity \pm 0.05 S.E. 


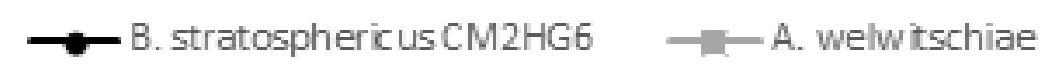

30

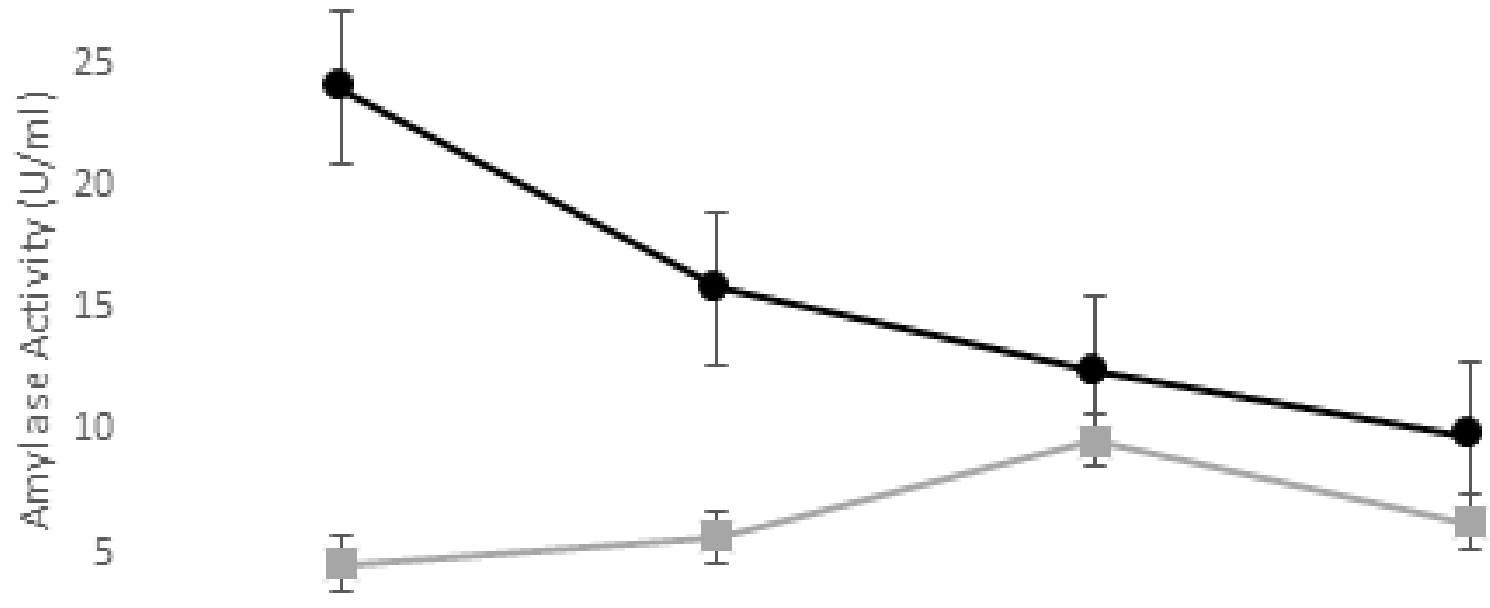

0

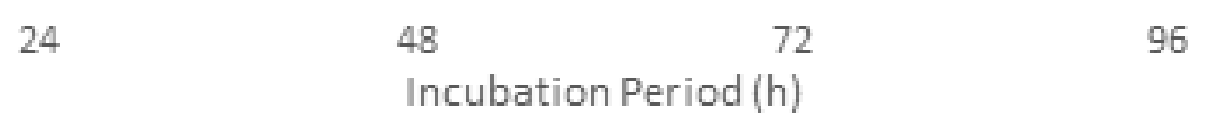

(a)

- B. stratosphericus CM2HG6 - - A. welwitschiae

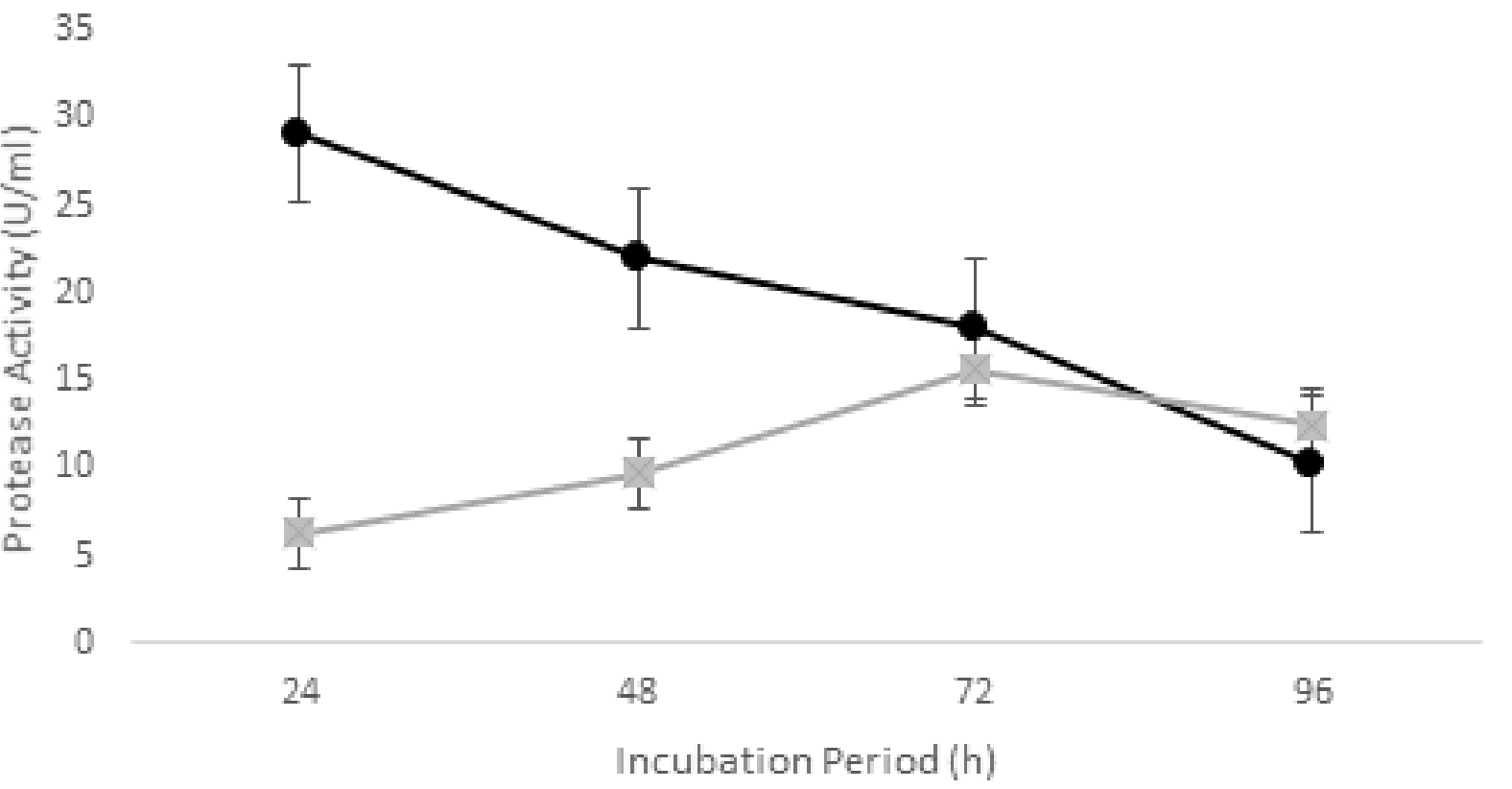

Figure 4: Optimization of (a) Amylase and (b) Protease production by B. stratosphericus CM2HG6 and $A$. welwitschiae based on Incubation Period \pm 0.05 S.E. 
Table 2: Amylase and Protease Production by Bacillus stratosphericus CM2HG6 and $A$. welwitschiae under Optimized Conditions

\begin{tabular}{lll}
\hline Isolates & $\begin{array}{l}\text { Amylase activity } \\
(\mathrm{U} / \mathrm{ml})\end{array}$ & $\begin{array}{l}\text { Protease activity } \\
(\mathrm{U} / \mathrm{ml})\end{array}$ \\
\hline Bacillus stratosphericus CM2HG6 & 24.4 & 30.74 \\
A. welwitschiae & 12.58 & 18.8 \\
\hline
\end{tabular}

\section{DISCUSSION}

The waste water discharge from industries are major source of pollution and affect the ecosystem causing adverse effects on living organisms and agriculture, therefore the need to monitor their levels in the environment (Anikwe and Nwobodo, 2006). Dairy industries' effluents contain large quantities of fat, casein, lactose, and inorganic salts and these affect the Biological Oxygen Demand (BOD) which is a result of the amount of nutrients present for microbial metabolism in the ecosystem. The BOD observed in the present study is many folds lower than reported in other studies (Verma and Singh, 2017).

Hydrogen ion concentration $(\mathrm{pH})$ is a largely studied ecological parameter, and it can affect the rate of biological reaction and survival of various microorganisms. Neutral to alkaline $\mathrm{pH}$ was observed in the effluent and this favours bacterial growth over fungal growth. Fungi grow best in acidic environments, and the isolation of more bacterial species is in agreement with Pawar and Kolhe (2011) that reported similar $\mathrm{pH}$ range of $6-$ 9.5 in dairy effluent.

There is paucity of reports of indigenous microorganisms in dairy effluent, and this could be due to the fact that nutrient availability in effluent changes when they enter into different environments. Jain et al. (2001) reported isolation of different bacilli species including Bacillus megaterium and B. cereus. Isolation of Lactobacillus $s p$., an isolate indigenous to dairy industries was also reported by Prakashveni and Jagadeesan (2012). Enterococcus sp., another lactic acidproducing bacterium, was also reported to be isolated from cheese whey (Mazzucotelli et al., 2013). Although it is mostly indigenous to the intestine of warm-blooded animals, Enterococcus sp. can be found in dairy waste they can grow in hostile environments of extreme $\mathrm{pH}$, temperatures, and salinity, and can use dairy nutrients as metabolic substrates (Martín-Platero et al., 2009).

Hydrolytic enzymes are the most commonly used enzymes in biotechnological processes, and of these, amylases (starch hydrolases) and proteases (protein hydrolases) represent the dominant enzymes (Jamrath et al., 2012). Therefore, production of both enzymes by Bacillus stratosphericus $\mathrm{CM} 2 \mathrm{HG} 6$ and A. welwitschiae could be a desirable industrial characteristic. Proteolytic enzyme is found in all living organisms because it is an essential enzyme required for cell growth and differentiation. Isolation of protease and lipaseproducing species of Bacillus has been reported by Mazzucotelli et al. (2013). Bacillus caldolyticus isolated from food industries' effluent was also reported to produce both amylase and protease. Isolation of $A$. niger from dairy effluent was also reported by Lanka et al. (2017).

Incubation temperature also plays an important role in enzyme production and growth of microbes can be activated at one temperature and inhibited at another. It also influences the synthesis and secretion of enzyme production by changing the physical properties of the cell membrane (Balaji et al., 2012). Optimum enzymes production at $35{ }^{\circ} \mathrm{C}$ for both bacterial species indicates that the isolates are mesophilic organisms. Similar isolates have also been reported by Genckal and Tari (2006) for protease production by two Bacillus species.

$\mathrm{pH}$ of the fermentation medium is one of the most important factors affecting enzyme production as microbial cells have no mechanism to adjust their internal $\mathrm{pH}$ and hence alteration in optimum $\mathrm{pH}$ range results in poor growth of microbes and hence poor enzyme production (Bhattacharya et al., 2011). It also influences the 
transport of compounds across the cell membrane. Similar optimum $\mathrm{pH} 7$ observed in this study has also been reported by Raj and Hemashenpagam (2012) for amylase production from Bacillus sp., and 6.8 as optimum $\mathrm{pH}$ for the production of amylase by Bacillus subtilis. Similarly, optimum $\mathrm{pH}$ of 7.0 was reported by Chandrasekaran et al. (2015) for protease produced by $A$. niger isolated from paddy soil, while similar observations were reported by Radha etal. (2011).

Optimization of incubation period is very much essential as organisms show considerable variation in enzyme production at different incubation periods (Kumar et al., 2012). Optimum incubation period of $72 \mathrm{~h}$ for enzyme production by $A$. nigerindicates that the isolate produces more of the enzyme during its final stage of growthsporulation. Other studies however, reported different optimum incubation periods. Also, enhanced extracellular protease production by Aspergillus fumigatus and $A$. flavus isolated from local rice husk dump sites after $144 \mathrm{~h}$ of incubation period was reported by Oyeleke et al. (2010), while highest alkaline protease production was reported after $168 \mathrm{~h}$ of incubation by Penicillium chrysogenum (Sethi and Gupta, 2015).

\section{CONCLUSIONS}

This study successfully screened for protease and amylase-producing isolates from the dairy effluent. Out of the eleven species isolated and screened, one bacterium and one mold were investigated to possess protease and amylaseproducing properties. They were characterized to obtain their optimum production conditions respectively. Evidence of low amount of physicochemical parameters showed that the dairy effluent present in the environment would only be an issue after a long period of accumulation. The study also revealed that the indigenous microorganisms present in the dairy effluents were due to the fact that nutrient availability changes when effluents are discharged into the environment. This invariably suggests that substrates required for production of these enzymes were available for protease and amylase producing microorganisms than for other enzymes such as lipase.

\section{REFERENCES}

Anikwe, M. and Nwobodo, K. 2006. Long term effect of municipal waste disposal on soil properties and productivity of sites used for urban agriculture in Abakaliki, Nigeria. Bioresource Technology, 83:241-251.

APHA 2005. Standard Methods for the Examination of Water and Wastewater. $21^{\text {th }}$ edition American Public Health Association, Washington D. C.

Balaji, N., Rajasekaran, K. M., Kanipandian, N., Vignesh, V. and Thirumurugan, R. 2012. Isolation and screening of proteolytic bacteria from freshwater fish Cyprinus carpio. International Multidisciplinary Research Journal, 2: 56-59.

Bernfeld, P. 1955. Amylases: Alpha and Beta. Methods in Enaymology, 1:149-158.

Bhattacharya, S., Bhardwaj, S., Das, A. and Anand, S. 2011. Utilization of sugarcane bagasse for solid- state fermentation and characterization of $\alpha$ - amylase from Aspergillus flavus isolated from Muthupettai Mangrove, Tamil Nadu, India. Australian Journal of Basic and Applied Sciences, 5: 1012- 1022.

Chandrasekaran, S., Kumaresan, S. S. P. and Manavalan, M. 2015. Production and optimization of protease by filamentous fungus isolated from paddy soil in Thiruvarur District Tamilnadu. Journal of Applied Biology and Biotechnology, 3: 66-69.

Chhonkar, P.K., Datta, S.P. Joshi, H.C. Pathak, H. 2000. Impact of industrial effluents on soil health and agriculture Indian experience: Part-II-Tannery and textile industrial effluents, Journal of Scientific and Industrial Research, 59: 446-454.

Fossi, B. T., Tavea, F. and Ndjouenkeu, R. 2004. Production and partial characterization of a thermostable amylase from Ascomycetes yeast strain isolated from starchy soil. African Journal of Biotechnology, 4:14-18.

Genckal, H. and Tari, C. 2006. Alkaline protease production from alkalophilic Bacillus sp. isolated from natural habitats. Ensyme and MicrobialTechnology, 39(4): 703-710.

Jain, N., Nanjundaswamy, C., Minocha, A. K. and Verma, C. L. 2001. Isolation, Screening and Identification of Bacterial strains for 
degradation of predigested distillery wastewater. Indian Journal of Experimental Biology, 39: 490-492.

Jamrath, T., Linder,C. Popovic,M.K. and Bajpai, R. 2012. Production of Amylases and Proteases by Bacillus caldolyticus from Food Industry Wastes. Food Technology and Biotechnology, 50(3):355-361.

Kumar, D. J. M., Venkatachalam, P., Govindarajan, N., Balakumaran, M. D. and Kalaichelvan, P. T. 2012. Production and purification of alkaline protease from Bacillus sp. MPTK 712 isolated from dairy sludge. Global Veterinaria, 8:433-439.

Lanka, S., Anjali, C. H. and Pydipalli, M. 2017. Enhanced production of alkaline protease by Aspergillus niger DEF 1 isolated from dairy form effluent and determination of its fibrinolytic ability. African Journal of Microbiology Research, 11(11): 440-449.

Lechuga, E. G. O, Zapat, I. Q. and Nino, K. A. 2016. Detection of extracellular enzymatic activity in microorganisms isolated from waste vegetable oil contaminated soil using plate methodologies. African Journal of Biotechnology, 15(11): 408-416.

Martín-Platero, A. M., Valdivia, E., Maqueda, M and Martinez-Bueno, R. 2009. Characterization and safety evaluation of Enterococci isolated from Spanish goats' milk cheeses. International Journal of FoodMicrobiology, 132: 24-32.

Mazzucotelli, C. A., Ponce, A. G., Kotlar, C. E. and Moreira, M. D. R. 2013. Isolation and characterization of bacterial strains with a hydrolytic profile with potential use in bioconversion of agroindustial byproducts and waste. Food Science and Technology Campinas, 33(2): 295-303.

Oyeleke, S. B., Egwim, E. C. and Auta, S. H. 2010. Screening of Aspergillus flavus and Aspergillus fumigatus strains for extracellular protease enzyme production. Journal of Microbial Antimicrobiology, 2:83-87.

Padma, S. and Pallavi, K. 2016. Isolation and Characterization of Amylase Producing Bacillus species from Selected Soil Sample. International Journal of Research in Biosciences, 5(2):24-29.

Pawar, V. P. and Kolhe, A. S. 2011. Physico-
Chemical analysis of effluents from dairy industry. Recent Research in Science and Technology, 3(5):29-32.

Porwal, H.J., Mane, A.V. and Velhal, S.G. 2015. Biodegradation of dairy effluent by using microbial isolates obtained from activated sludge. World Research Industrial, 9:1-15

Prakashveni, R. and Jagadeesan, M. 2012. Isolation, identification and distribution of bacteria in Dairy Effluent. Advances in Applied Science Research, 3 (3):1316-1318.

Radha, S., Nithya, V. J., Himakiran, B. R., Sridevi, A., Prasad, N. B. L. and Narasimha, B. 2011. Production and optimization of acid protease by Aspergillus sp under submerged fermentation. Archive of Applied Sciences Research, 3: 155-163.

Raj, V. and Hemashenpagam, N. 2012. Production and medium optimization of amylase by Bacillus using fermentation methods. Journal of Microbiology and Biotechnology Research, 2 (4):481-484.

Raju, E. V. N. and Divakar, G. 2013. Production of pectinase by using Bacillus circulans isolated from dump yards of vegetable wastes. International Journal of Pharmaceutical Sciences and Research, 4(7): 2615-2622.

Raveendran, S., Parameswaran, B., Ummalyma, S.B., Abraham, A., Mathew, A.K. Madhavan, A. Rebello, S. and Pandey, S. (2018). Applications of Microbial Enzymes in Food Industry. Food Technology and Biotechnology, 56 (1): 16-30.

Sally, N. J. 2000. Purification and characterization of a novel protease from Burkholderia strain 2.2N Blacksburg, Virginia

Samanta, A. K.; Jayapal, N.; Semani, S.; Kolte, A.P. and Sridhar, M. 2013. Prebiotic inulin: Useful dietary adjuncts to manipulate the livestock gut microflora. Brazillian Journal of Microbiology, 44(1): 1-14.

Sethi, S. and Gupta, S. 2015. Optimization of protease production from fungi isolated from soil. International Journal of Applied Biology, Pharmacy and Technology, 6:149-154.

Sevinc, C., Tomas. L.B. and Friedrich. D. (2011). Protease production with cells of Bacillus sp. International Journal of Biotechnology, 5(6): 66-69.

Sharma, K. M.; Kumar, R.; Panwar, S. and Kumar, 
A. 2017. Microbial alkaline protease: Optimization of production parameters and their properties Journal of Genetic Engineering and Biotechnology, 15: (1):115126.

Srimathi, N., Subiksha, M., Abarna, J. and Niranjana, T. 2020. Biological Treatment of Dairy Wastewater using BioEnayme from Citrus Fruit Peels. International Journal of Recent Technology and Engineering, 9(1):292-295.

Tamura, K., Peterson, D., Peterson, N., Stecher,
G., Nei, M. and Kumar, S. 2011. MEGA: Molecular Evolutionary Genetics analysis using maximum likelihood, evolutionary distance and maximum parsimony methods. Molecular Biology and Evolution, 28: $2731-2739$.

Verma, A. and Singh, A. 2017. Physico-chemical analysis of dairy industrial effluent. International Journal of Current Microbiology and Applied Sciences, 6 (7):1769-1775 